International Journal of Business Economics (IJBE)

Vol, 1 Issue 2, pp 87-101, March 2020

http://jurnal.umsu.ac.id/index.php/ijbe

eISSN 2686-472X

ORIGINAL ARTICLE

\title{
Contribution of Tax Consultancy Firm in the Reduction of Tax Evasion in Cameroon
}

\section{Tambi Andison Akpor}

\begin{abstract}
This study attempts to examine the Contribution of Tax Consultancy Firm in the Reduction of Tax Evasion in Cameroon. The objectives are to: explore the contribution of Management of Tax Accounting Consortium (MTA) in the reduction of tax evasion in companies and to investigate the consequences of tax evasion on the tax payer enterprise. Methodologically, we used focus group discussion and quantitative data collected from MTA to estimate our result. The result shows that consultancy firm plays a major role in the reduction of tax evasion. Result by tax payer enterprise shows that companies that evade tax being good, bad or fraudulent faith end up losing much money that may lead to the collapse of the company. We recommend that tax payers should pay their taxes at the appropriate periods and rightly calculated to avoid penalties and interests. The government of Cameroon should absolutely encourage the growth of tax consultancy firms; it's a wise step towards economic growth.
\end{abstract}

Keywords: Contribution, Tax, Consultancy Firm, Reduction, Tax Evasion MTA

DOI :https://doi.org/ 10.30596/ijbe.v1i2.3485

JEL Classification: G00, H26

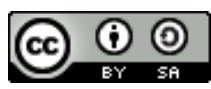

Published byInternational Journal of Business Economics (IJBE), Indonesia | Copyright (C) 2020 by the Author(s) | This is an open access article distributed under the Creative Commons Attribution License http://creativecommons.org/licenses/by/4.0), which permitsunrestricted use, distribution, and reproduction in any medium, provided the original work is properly cited.

Cite this article as:

Akpor, T. A. (2020). Contribution of Tax Consultancy Firm in the Reduction of Tax Evasion in Cameroon. International Journal of Business Economics (IJBE), 1(2), 87101.

Department of Management Science;

University of Dschang, Cameroon

*Corresponding Author: andybest40@yahoo.com 


\section{International Journal of Business Economics (IJBE)}

Vol, 1 Issue 2, pp 87-101, March 2020

http:/ /jurnal.umsu.ac.id/index.php/ijbe

eISSN 2686-472X

\section{INTRODUCTION}

Taxation is a major source of revenue to most central governments and determinant of economic and development. This explains why tax evasion has been a matter of great concern for both tax authorities and taxpayers. Historically as revealed by Ndjallè (2017), the property tax in Cameroon starts during the fiscal year 1987/1988. Since its early beginning, the answer to the question "What is the property tax in Cameroon" has remained the same. According to the articles 579 and 580 of the current tax code, the property tax is a tax due because of the ownership or the occupancy of a land, vacant or not. However, the designation of the taxable properties has changed many times between 1987/1988, and 2006 (Daphne et al., 2012).

In fact, from the fiscal years $1987 / 1988$ to $1993 / 1994$, all properties were in the scope of the property tax; however, this wide extension of the tax basis was unrealistic. Then a correction was brought from 1994/1995, limiting the liability to the property tax to properties vacant or not, situated in the headquarters of administrative units. But a new provision was added in 2006, stating that properties situated in the agglomerations benefiting unban infrastructure (water, telephone, electricity, paved or motorable roads) were also subject to the tax (Ndjallè, 2017). As for what concerns the rates, they have moved from the flat tax rates, according to the slices of square meters, in 1987/1988, plus $25 \%$ of the principal tax awarded to local councils (Daphne et al., 2012), to $0.1 \%$ of the value of properties in 2006, plus $10 \%$ of the principal tax devoted to local councils (see table 1). Besides, since the year 2009 the property tax is henceforth a tax product collected by the General Direction of Taxation (GDT) for the exclusive benefit of local councils. In the meantime, the number of exemptions has increased, including wealthier taxpayers, such as industrial for spaces devoted to industrial activities, leaving aside poor and needy people.

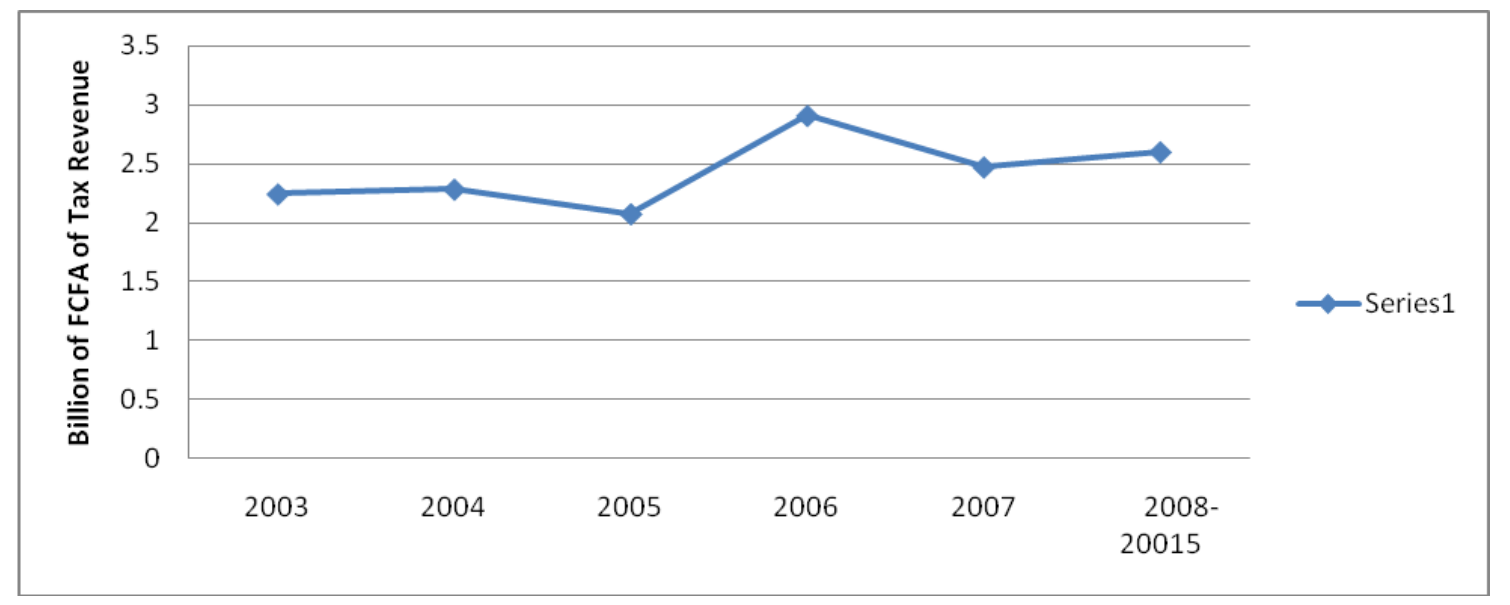

Figure 1: Evolution of Tax Revenue from 2003 to 2015 in North West Region of Cameroon Source: Author, from statistics of the General Directorate of Taxation website

In a nutshell, the observations above underline the failure of the self-assessment tax system in force in Cameroon regarding the property tax. Even if the Tax Administration can reassess the values declared by taxpayers in their returns, this usually feeds more a system of corruption based on the bargaining of the tax basis. This fainting is moreover exacerbated likewise by some defaults of clarity of key notions such as the value of assessment, and the situation of properties subject to the tax. Similarly, even the granting of exemptions 


\section{International Journal of Business Economics (IJBE)}

Vol, 1 Issue 2, pp 87-101, March 2020

http://jurnal.umsu.ac.id/index.php/ijbe

eISSN 2686-472X

disrespects the principles of equity and taxation according to the ability to pay. All these factors combined contribute to lower the yield of the property tax.

Tax evasion is both phenomena that are probably as old as taxation itself. Wherever and whenever authorities decide to levy taxes, individuals and firms try to avoid paying them. Though this problem has always been present, it becomes more pressing in the course of globalization as this process extends the range of opportunities to circumvent taxation while simultaneously reducing the risk of being detected. In the last couple of years, strengthening self financing capacities of development countries has become a topic of increased concern and interest (Dalu et al., 2012). Domestic revenue mobilization as a central issue of the international development agenda has been emphasized in both the Monterrey Consensus and the Paris Declaration on Aid Effectiveness. This is due to a number of reasons. Firstly, the establishment of own revenue raising abilities is crucial for any state as it constitutes a prerequisite to ensure a sustainable development process and implement pro-poor policies. Since self-financing capabilities in developing countries are often not sufficient, generating tax revenue is highly relevant for many developing countries.

Secondly, fair and efficient tax systems can contribute to good governance, accountability of the state and democracy by establishing a bargaining process between the state and its citizens: Governments that rely on broad based taxation are forced to take the demands of their taxpayers into account. At the same time, the way in which a government levies taxes essentially affects the citizen's identification with the state and its governmental agencies, potentially increasing trust and compliance of its citizens and ultimately promoting political participation. Thus, besides generating public revenues, strengthening tax systems in developing countries is equally important from a governance or state-building perspective (Dalu et al., 2012). Thirdly, revenue raising systems typically include the entire population, thereby exhibiting a direct effect on the poor and their household income. Designing a tax system in a pro-poor way can e.g. be achieved by including a redistributive component. All in all, collecting a sufficient amount of revenues is essential for a country to fund pro-poor programs, built effective government institutions and strengthen democratic structures, stimulate sustainable economic growth and reach national and international development goals. To reach these goals it is, however, essential that the tax system is implemented the way it was designed. Thus, counterproductive activities like tax evasion and avoidance practices, that undermine the intentions of the system, need to be reduced.

An analysis of the property tax in Cameroon, reveals that this tax is lowest paid, in view of the large number of people owning real estate (Daphne et al., 2012). Whereas, over the years, revenue derived from taxes has been very low and no physical development actually took place, hence the impact on the poor is not being felt. It is the view of many people that the loss of revenue caused by widespread tax evasion in Cameroon is due to inefficient and inept tax administration. Omorogiuwa (1981) has opined that ineffective tax administration is the main factor responsible for large scale tax evasion in countries. Despite the constant process of refinement of the corporate tax in Cameroon, it is obvious that the corresponding revenues are far from being consistent. Just for illustrative purpose, with the introduction of the taxation according to the value of real estates, the revenue of the tax sunk in 2006 (Daphne et al., 2012). Unfortunately, even before that time and until now, the corporate tax revenue is stuck around 2 billion per year. It represents only $0.15 \%$ of the total taxes collected by the ministry of finance, and only $1.68 \%$ of the fiscal revenues of the local community of Douala, the engine of the Cameroonian economy (Ndjallè, 2017). 


\section{International Journal of Business Economics (IJBE)}

Vol, 1 Issue 2, pp 87-101, March 2020

http://jurnal.umsu.ac.id/index.php/ijbe

eISSN 2686-472X

In addition, for the Cameroonian Ministry of Finance, in an interview published in January 2014 in the website http://www.agenceecofin.com, the potential yield of the business tax is at least 8 billion; therefore, the collection gap is around 6 billion (Daphne et al., 2012). This negative trend is confirmed by the General Director of Taxation, who recognizes, in an announcement published in the taxation website http://www.impots.cm in April 2016, that the number of taxpayers paying their corporate tax is only 138510 in 2015, whereas this number could be raised to 1163510 , based on statistics held by the General Direction of Taxes, in connection with different entities dealing with real estate owners (Ndjallè, 2017). As noted in the literature, the primary way which money flows out of countries is through tax offset. In its simplest form this entails three steps. Firstly, a corporation working in a developing country sets up a subsidiary in a tax haven. Secondly, they sell their product at an artificially low price to this subsidiary enabling them to declare minimal profits and consequently pay very little tax to the government of the developing country. Thirdly, their subsidiary in the tax haven sells the product at the market price for comparatively huge profits coupled with a low tax rate (or none at all) (Ndjallè, 2017). In other words, corporations are manipulating prices to pay minimal taxes.

Tax evasion is major facilitator of poverty, crime, and corruption in developing countries like Cameroon. Tax haven secrecy drains nearly $\$ 1$ trillion from each year from the country. This is money that could have been spent on health care, education, and infrastructure, while banks play a critical role in the global economy and many countries' tax systems; many have also played a significant part in facilitating tax evasion schemes, thereby reducing revenue generated by government both at the central and local government level. This study provides a framework and guidelines through which substantial knowledge of the research study can be understood (Ndjallè, 2017). Therefore, in order to increase the effectiveness and the efficiency of tax revenue collection, it is important to examine the intricacies surrounding tax evasion tendencies. To do this, this study sets out to address a number of objectives: Explore the contribution of MTA in the reduction of tax evasion in companies and investigate the consequences of tax evasion on the tax payer enterprise

Tax evasion in general refers to illegal practices to escape from taxation. To this end, taxable income, profits liable to tax or other taxable activities are concealed, the amount and/or the source of income are misrepresented, or tax reducing factors such as deductions, exemptions or credits are deliberately overstated (see Alm and Vazquez, 2001 and Chiumya, 2006). Tax evasion can occur as an isolated incident within activities that are in other aspects legal. Or tax evasion occurs in the informal economy where the whole activity takes place in an informal manner this means the business is not only evading tax payments but is also not registered as formal enterprise at all. Tax evasion and its sister tax avoidance are key fundamental problems of tax administration in a developing country like Nigeria. All forms of taxes in Nigeria are to some extent avoided or evaded because the administrative machinery to ensure effectiveness is weak. As a result of the diversities and complexity in human nature and activities, no tax, law can capture everything hence; loophole will exist and can only be reduced or eliminated through policy reforms.

Thus, besides generating public revenues, strengthening tax systems in developing countries is equally important from a governance or state-building perspective. Thirdly, revenue raising systems typically include the entire population, thereby exhibiting a direct effect on the poor and their household income. Designing a tax system in a pro-poor way can e.g. be achieved by including a redistributive component. All in all, collecting a sufficient amount of revenues is essential for a country to fund pro-poor programs, built effective 


\section{International Journal of Business Economics (IJBE)}

Vol, 1 Issue 2, pp 87-101, March 2020

http://jurnal.umsu.ac.id/index.php/ijbe

eISSN 2686-472X

government institutions and strengthen democratic structures, stimulate sustainable economic growth and reach national and international development goals. To reach these goals it is, however, essential that the tax system is implemented the way it was designed. Thus, counterproductive activities like tax evasion and avoidance practices, that undermine the intentions of the system, need to be reduced.

The present study aims at developing a deeper understanding of the problem of tax evasion and avoidance in developing countries. Against the background of growing interest by international development cooperation, governments of developing and developed countries and international institutions in this topic, this study shall contribute to the systematization of knowledge. It becomes apparent that although there is a theoretical basis explaining tax evasion and tax avoidance behavior, we know little about the patterns and the extent of tax evasion and avoidance in the regions of the world and the different techniques used to evade and avoid paying taxes in individual developing countries. Fiscal policy measures in Africa have been largely driven by the need to promote such macroeconomic objectives as raising revenue to finance rapid economic growth of their economies, generating employment, maintaining price level and exchange rates stability and balance of payments equilibrium. To achieve these objectives one of the ways of dealing with taxation problems is to deal with harmful taxes practices (Alm et et al., 1990).

From personal observation, it was noted that partial evasion maybe due to inadequate accounting records maintained by traders, mistaken beliefs on part of some illiterate taxpayers that only wages and salaries represent tax income. It apparent that, the spirit of unpatriotism has gripped a lot of tax payers as they fail to understand why they have to remit their hard earned profits to the government and thus they try by all means to come up with different sets of accounts indicating a loss. One notable feature of literature on tax evasion is that it often assumes a corruption-free tax administration (Poterba, 1987). The reason for this is partly because tax evasion research has assumed the institutional environment of developed countries. In these economies corruption is not a serious problem, particularly in tax administration. However, in developing countries, corruption poses serious concerns by affecting a greater part of the economy. The importance of corruption has been noted by many economists (Rose-Ackerman, 1978). It is widely believed that corruption perpetrated and executed by revenue officials is a prevalent phenomenon that can seriously hamper investment, economic growth, and stability of socio-economic institutions. Corruption in tax administration affects the level of tax revenue that can be collected in developing countries. Some economists argue that it is more important than the tax rate policy.

\section{METHODS}

\section{Model Analyzing the Contribution of MTA on Tax Evasion}

The main method applied in this study to determine the contribution of MTA on tax evasion is that of focus group discussion and quantitative data derived MTA data bank. Focus groups are often used to explore subjective meaning and understanding and are particularly useful to identify relevant domains when developing questionnaires (Morgan, 1997). Focus groups have been used successfully to explore the perspective of children and young people in health, education and psychology research (Ellermann, 2007). There is also a growing body of work that has used focus groups to understand how tax payers perceive quality of life and traditional practices preferred by an ethnic subgroup concerning government revenue (Beresford et al., 2007). Assessing levels and ways of tax evasion on various domains of businesses is a key component of measuring health, evaluating the impact of government 


\section{International Journal of Business Economics (IJBE)}

Vol, 1 Issue 2, pp 87-101, March 2020

http://jurnal.umsu.ac.id/index.php/ijbe

eISSN 2686-472X

expenditure and interventions on state affairs. Meaningful comparisons across groups are useful in setting goals for the improvement of the general economy and charting progress towards attaining government goals. In this study, a total of four focus group discussions are carried out with men and women of the working age (20-50 years old) in three different business structures (MTA, Ets Tsayem Moses, CAMSUBA and UNDVA), to assess their perceptions and knowledge on the contribution of Management of Tax Consultancy Consortium on tax evasion in their businesses and the economy of Cameroon as a whole. The different groups are selected based on their enterprise of affiliations.

\section{Research Instruments to Gauge the Role of Accounting Firm on Tax Evasion}

Focus groups are a powerful instrument often used to understand the influence of a variable on other variables, in this study; we explored what the people say on the role of accounting firm on tax evasion with the use of FGD as our instrument of measurement (Ronen et al., 2001). FGD has been used as a powerful research instrument in many contemporary studies (for example, Wee et al., 2006). Focus groups was also used to ask business owners about what constitutes their business wellbeing vis-à-vis accounting firm in an Australian study interested in developing tax-centred indicators (Fattore et al., 2009) and more specifically with small and medium size enterprises in relation to outcomes from support services (Beresford et al., 2007). Accounting effects are increasely being sought and reported to feed into policy and practice development. For example, Counterpoint qualitative research sought to identify factors comprising a good content in taxation. They found that business owners and hawkers identified a similar range of issues as owners but used different techniques (Counterpoint, 2008).

\section{Reliability and Validity of focus group Data}

Focus group data can be tested for reliability by comparing the responses of focus groups, for instance, if most groups mention accounting firm as a major adviser of business owners on issues related to taxation, then one can be confident of the reliability of reporting. However, if no two groups give the same response as an explanation of taxation, then one cannot place too much faith in the reliability of the responses. Secondly, one can also compare focus group findings with those from other methods of data collection such as MTA quantitative as noted below. The narrative statements in methodology demonstrate another example of reliability testing across groups. Each of the three groups gave similar answers with respect to MTA input, benefit and complementary activities, even though each group's answers were expressed in different ways. In order to avoid jeopardizing the validity of focus group data, every precaution was taken to avoid finishing participant's responses or asking leading questions that can hinder validity. Since the purpose of a focus group is to gather data relevant to the respondents' point of view not to provide them with 'correct' textbook responses. This of course does not preclude the appropriateness of giving information in response to questions raised by those being interviewed. Ideally, such a question-and-answer session should be separated from data collection by a clear break in the proceedings.

\section{Data Source and Sample Characteristics Focus group aims, access and sampling}

As seen above, the principal aim of this chapter is to examine what the people say on contribution of MTA on tax evasion, evidence from what the people say. The principal role of the focus group is to examine in real terms how better MTA intervention can directly or indirectly affect businesses in terms of tax evasion. We adopt an approach based on three principal businesses and men and women familiar with issues related to taxation and tax 


\section{International Journal of Business Economics (IJBE)}

Vol, 1 Issue 2, pp 87-101, March 2020

http:/ /jurnal.umsu.ac.id/index.php/ijbe

eISSN 2686-472X

professional firms. To ensure proper comparism of the FGD and the result obtain from quantitative information or to avoid any problem of bias in noting what the people say, our adoption of expert groups is based on those used to paying the enterprise tax or attending related workshops. To ease organization, logistics and the flow of discussions, the group meeting of the discussants was centre in the staff office of the enterprise.

There are many reasons why we chose to work with pre-existing groups - clusters of people who already knew each other through living, working or socializing together. We did this in order to explore how people might talk about MTA and Tax evasion within the various and overlapping groupings within which they actually operate. Flat mates, colleagues, family and friends - these are precisely the people with whom one might 'naturally' discuss such topics as tax policy (Middleton and Edwards, 1990). Although the practice of using existing friendship groups is discouraged by standard market research texts such fear seemed unjustified in our case. By using pre-existing groups we shall be able to tap into fragments of interactions which is approximated to 'naturally occurring' data. The fact that research participants already knew each other had the additional advantage that friends and colleagues could relate each other's comments to actual incidents in their shared daily lives. They often challenged each other on contradictions between what they are professing to believe and how they actually behaved.

Above all it is useful to work with pre-existing groups because they provide one of the social contexts within which ideas are formed and decisions made. Khan and Manderson (1992) recommended the explicit use of informal as well as formal 'focus groups' for anthropological research into understandings of tax in village settings. They worked with groups composed, for example, of a woman, her daughter, daughter-in-law and unrelated immediate neighbours. Such natural clustering of people' they pointed out, 'represent in a loose fashion the resources upon which any member of the group might draw information and advice. This is a group that may weave or repair nets together while watching over their business and discussing the events of the previous day. It is precisely this natural social network which provides the scripting for the management of an illness event-what to do with a business, for example how to pay taxes to the tax administrators even when the business is not faring well (Khan and Manderson, 1992). Also it's worth mentioning that the choice of our sample occupation is very important because these are jobs that highly compete with time so far as the taxation policy is concern.

\section{Focus group design, operation and analysis}

The basic topics and domains discussed in the focus group are indicated below. An initial definition for each topic is developed to facilitate the discussions and to identify initial areas of overlap or content that might warrant separation into new topics. This is listed below with some information about the use of the domain in other outcome assessment scales.

Table 1: Domains developed for focus groups

Topic of Discussion

Origin of business and Tax payment

Awareness of Taxation Policy

\section{Domain}

Here we are interested to know when the business owner actually started, how the business was registered, when the first tax payment was made and the amount actually paid in.

Our objective is to determine the awareness of tax payer on the taxation policy, 


\section{International Journal of Business Economics (IJBE)}

Vol, 1 Issue 2, pp 87-101, March 2020

http:/ /jurnal.umsu.ac.id/index.php/ijbe

eISSN 2686-472X

\begin{tabular}{|c|c|}
\hline Topic of Discussion & Domain \\
\hline Awareness of the existence of MTA & $\begin{array}{l}\text { We wish to know if the business managers are aware of the } \\
\text { existence of professional firms, accounting firms, taxation experts } \\
\text { apart from the tax administrators that can help them understand } \\
\text { the tax principles better, advice them, guide them on how to } \\
\text { function well with the tax payment vis-à-vis their business } \\
\text { activities. }\end{array}$ \\
\hline $\begin{array}{l}\text { Assistance from MTA or any other } \\
\text { accounting firm }\end{array}$ & $\begin{array}{l}\text { The objective here is to know their business functioning mode } \\
\text { with respect to the accounting firm; does the business consult the } \\
\text { professional firm when they want to deal with tax affairs? How } \\
\text { the business managers do relates with tax experts? Is the tax } \\
\text { expert that pays the tax for the business? Who calculate the tax? }\end{array}$ \\
\hline $\begin{array}{l}\text { Necessity and continuation of working } \\
\text { with tax expert }\end{array}$ & $\begin{array}{l}\text { Here we suppose that the business managers know the importance } \\
\text { of tax expert, will they want to continue to work with the experts? }\end{array}$ \\
\hline $\begin{array}{l}\text { Decision Making concerning Tax } \\
\text { decisions }\end{array}$ & $\begin{array}{l}\text { We are interested to know, who actually takes decisions } \\
\text { concerning tax payment }\end{array}$ \\
\hline
\end{tabular}

Source: author (designed for FGD)

To realize our objective, we make use of the business authorities to establish the focus group in their respective business site. At the start of the group meeting, the project and the aims of the discussion were outlined. Confidentiality and anonymity was explained and the ground rules of group discussions outlined and consent forms collected. The groups start with the participants, including the moderator (researcher) taking in turns to introduce themselves and tell the group the best thing they had done during the rainy season and what they are looking forward to do in the next season or so. A structured topic guide is used by the moderator. This guide includes open questions similar to those used by Beresford et al (2009). Open questions are asked first and so on. To encourage and maximize participation, participants are asked to provide more detail information, to elaborate further or to comment on something another participant had said. Table 2 shows the number and percentage of female and male participants in the focus group.

Table 2. Number of Focus Group participants

\begin{tabular}{lcccc}
\hline Focus Group & Female & Male & Female (\%) & Male (\%) \\
\hline Ets Tsayem Moses & 3 & 5 & 37.5 & 62.5 \\
CAMSUBA & 4 & 4 & 50 & 50 \\
UNDVA & 2 & 6 & 25 & 75 \\
Total & $\mathbf{9}$ & $\mathbf{1 5}$ & $\mathbf{3 7 . 5}$ & $\mathbf{6 2 . 5}$ \\
\hline
\end{tabular}

Source: author (designed for FGD)

\section{RESULT AND DISCUSSION}

\section{Findings from the focus groups and proposed set of outcome domains}

In this section, we present the findings of the different domains from what the people say from focus group discussions before finally presenting the main results of the FGDs in the contribution of accounting firm in reducing tax evasion. The participant's spontaneous responses to the open questions suggested that the six proposed domains are relevant and important. Spontaneous remarks were made that corresponded to some degree to our domains of accounting inputs and business setting. 


\section{International Journal of Business Economics (IJBE)}

Vol, 1 Issue 2, pp 87-101, March 2020

http://jurnal.umsu.ac.id/index.php/ijbe

eISSN 2686-472X

\section{Views about the Origin of business and Tax Payment}

In Table 3, we observe that all groups make mention of the business registration and had tax payer card however, about 66.65 percent of the businesses are greater than 10 years in business while about 53.33 percent started paying tax after exonerated period. All the enterprises said they received exonerated from tax for less than 2 years when just started.

Table 3. Summary of what the people say about the Origin of business and Tax Payment

\begin{tabular}{lcccc}
\hline \multicolumn{1}{c}{ Description } & $\begin{array}{c}\text { Ets Tsayem } \\
\text { Moses }\end{array}$ & CAMSUBA & UNDVA & $\begin{array}{c}\text { Groups Mention } \\
\text { item }(\%)\end{array}$ \\
\hline $\begin{array}{l}\text { Business register and had tax } \\
\text { payer card }\end{array}$ & 1 & 1 & 1 & 100 \\
$\begin{array}{l}\text { Greater than 10 years in } \\
\text { business }\end{array}$ & 1 & 1 & 2 & 66.67 \\
$\begin{array}{l}\text { Exonerated from tax for } \\
\text { years when just started }\end{array}$ & 1 & 1 & 1 & 100 \\
$\begin{array}{l}\text { Started paying tax after } \\
\text { exonerated period }\end{array}$ & 2 & 0 & 1 & 33.33 \\
\hline $\mathbf{N}$ & 4 & 4 & 4 & - \\
\hline
\end{tabular}

Source: author from FGD

NB: $0=$ if No, $1=$ if yes and $2=$ if don't know/don't remember

The table revealed that most of the enterprises are well experience, meaning that most of them have gone through many stages of tax payments and perhaps have work with tax professional experts. This means that our used of these structures to get our important is valid and sufficient to provide us with much relevant information.

\section{Views about the Awareness of Taxation Policy}

Concerning what the people say as detailed in table 5 shows that 66.67 percent of our enterprises are aware of the type of tax to pay. Knowledge of tax evasion with respect to good faith is 100 percent understood while the bad and fraudulent faith of tax evasion is just 66.67 percent understood. However, despite the awareness on the tax policy, most of the companies noted that the payment of tax is of no importance to them.

Table 4. Views about the Awareness of Taxation Policy as mentioned by focus group

\begin{tabular}{lcccc}
\hline Description & $\begin{array}{c}\text { Ets Tsayem } \\
\text { Moses }\end{array}$ & CAMSUBA & UNDVA & $\begin{array}{c}\text { Groups Mention } \\
\text { Item (\%) }\end{array}$ \\
\hline $\begin{array}{l}\text { Awareness of Type of Tax to } \\
\text { pay }\end{array}$ & 1 & 2 & 1 & 66.67 \\
$\begin{array}{l}\text { Knowledge of tax Evasion } \\
\text { Knowledge of good faith tax }\end{array}$ & 1 & 1 & 1 & 100 \\
$\begin{array}{l}\text { Evasion } \\
\text { Knowledge of bad faith tax }\end{array}$ & 1 & 1 & 1 & 100 \\
$\begin{array}{l}\text { Evasion } \\
\text { Knowledge of Fraudulent faith }\end{array}$ & 1 & 0 & 1 & 66.67 \\
tax Evasion & 0 & 2 & 1 & 66.67 \\
Importance of Tax payment & & 0 & 0 & 0 \\
\hline
\end{tabular}

Source: author from FGD

NB: $0=$ if No, $1=$ if yes and $2=$ if don't know 


\section{International Journal of Business Economics (IJBE)}

Vol, 1 Issue 2, pp 87-101, March 2020

http:/ /jurnal.umsu.ac.id/index.php/ijbe

eISSN 2686-472X

However, as noted in the scripture, all citizens of a country are morally and legally bound to pay their fair share of tax. Thus from above, we cover the importance of paying taxes to the government and why business owners should not do the mistake of hiding money or avoiding taxes. We observed in the field that a large percentage of business owners who pay tax think as if government is trying to steal their hard earned money, well that's not true. Money collected from taxes help the economy to become stronger and for the government to provide a variety of services to its citizens. Some examples of some services that government provides with business tax money are: (1) Infrastructure Projects: Government needs money to build roads, bridges, dams and number of other projects which are available to the society as a whole. (2) Public Security: Money collected from taxes is used to provide police and fire departments. It also helps to fund money needed to maintain defense forces (army, navy and air-force) and buy arms for them. (3). General services: Keeping roads clean, water treatment, street lights, trash removal and maintenance of public parks requires lot of money. (4). Health Services: Almost all governments provide some level of free or subsidized health services to its citizens. This may include preventive immunization shots, disaster relief and many others. All this money is funded by the tax money you and I pay. (5). The list goes on: Maintenance of historic monuments, government aid, emergency relief, conduct elections, run several government institutions like department for agriculture, commerce, energy, urban development, treasury, judiciary, department of motor vehicles etc.

Thus, Management of Tax Accounting Consortium will be helpful to business owners when dealing with corporate, income tax and related matter. It is important for business owners to educate themselves about tax using the internet. Further tax money also helps the nation to protect themselves (security) as tax covers the military expenses. It helps to develop the infrastructure of the state like Roads, hospitals, legal protection, welfare security, and environment, improve the standard of education. It will be able to provide education to all citizens and helps to increase the standard of living of the citizen. Business owners pay taxes so they can maintain a streamlined government. Taxes are like income for the government so that they can pay for socialized services within your country for service such as health care, pension funds, welfare, homeland security, war, etc. On the contrary, if no one is paying tax, the society would disintegrate, the nation would crumble. Therefore, it is important for every citizen of the state or business owner to pay tax regularly. Thus, business owners should not groan for the burden of the tax instead should think about the utilities that they receive from the tax. Thus payment of tax is like paying rent to live in a wonderful country.

\section{Views about the Awareness of the existence of MTA}

Views about the awareness of the existence of MTA; shows that 100 percent of the enterprises are aware of the existence of accounting firms. The equally revealed that their enterprises are closely working with MTA and they expect much from MTA.

Table 5. Views about the Awareness of the existence of MTA

\begin{tabular}{lcccc}
\hline \multicolumn{1}{c}{ Description } & $\begin{array}{c}\text { Ets Tsayem } \\
\text { Moses }\end{array}$ & CAMSUBA & UNDVA & $\begin{array}{c}\text { Groups Mention } \\
\text { Item (\%) }\end{array}$ \\
\hline $\begin{array}{l}\text { Do you know about MTA } \\
\begin{array}{l}\text { Does your enterprise work } \\
\text { with MTA }\end{array}\end{array} \quad 1 \quad 1000$ \\
$\begin{array}{l}\text { Are you expecting much from } \\
\text { MTA }\end{array}$ & 1 & 1 & 1 & 100 \\
\hline
\end{tabular}

Source: author from FGD

NB: $0=$ if No, $1=$ if yes and $2=$ if don't know 


\section{International Journal of Business Economics (IJBE)}

Vol, 1 Issue 2, pp 87-101, March 2020

http:/ /jurnal.umsu.ac.id/index.php/ijbe

eISSN 2686-472X

As noted in the literature, it is perhaps time to start paying more attention to where ones money is invested. Many investment firms with a socially responsible mandate say they do take account of companies' tax practices when deciding where to invest but few actually screen out companies over tax issues. However, some groups have said it was looking into excluding companies with what it called "overly aggressive tax reduction policies" from its ethical index group. No timings have been confirmed on this move, but the MTA stance may reflect a future trend.

\section{Contribution of MTA in the Reduction of Tax Evasion}

As already noted above; tax evasion in general refers to illegal practices to escape from taxation. To this end, taxable income, profits liable to tax or other taxable activities are concealed, the amount and/or the source of income are misrepresented, or tax reducing factors such as deductions, exemptions or credits are deliberately overstated (Chiumya, 2006). Tax evasion can occur as an isolated incident within activities that are - in other aspects - legal. Or tax evasion occurs in the informal economy where the whole activity takes place in an informal manner - this means the business is not only evading tax payments but is also not registered as formal enterprise at all. Tax evasion and its sister tax avoidance are key fundamental problems of tax administration in a developing country like Cameroon. All forms of taxes in Cameroon are to some extent evaded because the administrative machinery to ensure effectiveness is weak. As a result of the diversities and complexity in human nature and activities, no tax, law can capture everything hence; loophole will exist and can only be reduced or eliminated through policy reforms.

From the focus group discussion, we observed that the various group unanimously concluded that the following points are the contribution of MTA to the reduction of tax evasion in companies in Bamenda, North West Region.

- Address conflicts of interest in consulting for tax legislation: Most enterprises indicated that they contracted taxation consultants who provide technical advice to enterprises on tax planning strategies as well as recognized the potential conflicts of interest between business managers and tax administrators on issues related to the development of tax legislation.

- A professional service organization provides a code of ethical conduct that must be instated to ensure consistency across the various industries.

- Increased transparency and disclosure consolidation: A Consultancy firm ensures transparency and disclosure of taxes by the existing enterprises. This minimizes compliance burdens while maximizing transparency and public awareness, placing enterprise tax strategies under more scrutiny.

- Reduce and clarifies the complexities in tax payment and so easing the payment of tax. These advisors simultaneously provide strategies for clients to minimize tax burdens, representing a conflict of interest.

- Tax advisors provide advice to companies while utilizing their knowledge gained through consulting governments on tax legislation. This represents a serious conflict of interest. Solving global corporate tax avoidance needs to engage stakeholders who facilitate aggressive tax avoidance strategies.

- Tax-specific industry expertise of external audit firms played a significant role in client tax avoidance. Tax expertise develops tax strategies which benefit clients from accounting perspective. This result is consistent with the observation of Poterba (1987), 


\section{International Journal of Business Economics (IJBE)}

Vol, 1 Issue 2, pp 87-101, March 2020

http:/ /jurnal.umsu.ac.id/index.php/ijbe

eISSN 2686-472X

who found that firms who reduce or eliminate tax services provided by their auditor pay on average more taxes in the long term.

- Tax advisers who provide consultation to government on tax legislation are also better placed to identify loopholes for their corporate clients. This is apparent when observing advice given to clients. However, the purpose of government policy will not be realized if large tax advisory firms can leverage their knowledge of taxation systems to suggest ways of working around legislation to their client.

\section{Tax Evasion and Consequences on the Tax Payer Enterprise}

This second result is presented in function of tax evasion and the consequences associated to the functioning of the particular enterprise. The most commonly practice of the three categories of tax evasion such as good faith, bad faith and fraudulent faith is also computed and discussed. Therefore, focusing on the different penalties associated with tax evasion, we can identify three potential classifications of penalties i.e. Bad, Good and Fraudulent faith tax evasion.

\section{Good Faith Evasion of Tax Revenue and Consequences on the tax payer Companies}

As noted in tax evasion literature, Good faith penalty is a situation where the tax payer pays in the tax after the official due date of payment and after a notification letter is issued by the tax administration. This form of penalty is usually calculated as $30 \%$ times the principal amount of the tax. Considering the above selected three enterprises according to their current evasion of tax, we computed their total sum of penalty in an attempted to determine their impact in the tax payer enterprise. The sum is computed for three months of non-payment of tax and the range is from 2012 to 2017.

According to our result, we observed that, the Tsayem Moses enterprise dealing with hotel catering services for three consecutive times receives three notifications of good faith tax evasions. Normally, Tsayem enterprise pays as principal tax, 1355204 FCFA, 1355205F and 152464FCFA respectively, however, as a result of the tax due to the non-payment of tax, the total amount of penalty rose to $659859 \mathrm{~F}, 659859 \mathrm{~F}$ and $54886 \mathrm{FCFA}$ respectively. Adding these penalties to the principal tax sum, it resulted to a total tax amount of $2015063 \mathrm{~F}$, $2015063 \mathrm{~F}$ and 207350FCFA. Thus, implying that, the Tsayem Moses enterprise had to disburse about 4,237,476FCFA as tax due to evasion. This means that without the evasion, the Tsayem Moses enterprise could have paid for the three periods the sum of 2,862,872 which could have been the amount to enter the government treasury. CAMSUBA is a company dealing with general commerce, just like Tsayem Moses enterprise, evaded tax under the good faith regime for over three periods of tax payment, the amount for this period plus the penalty amounted to 6739369 FCFA which is money the general economy could have loss should incase the enterprise succeeded to evade the tax. The UNDVA corporate body dealing with the development of agricultural activities and agribusiness management on their part evaded tax on three conservative tax periods. This implies tax evasion is very detrimental to the tax payer enterprise. This result is clearly shown in table 6 . 


\section{International Journal of Business Economics (IJBE)}

Vol, 1 Issue 2, pp 87-101, March 2020

http:/ /jurnal.umsu.ac.id/index.php/ijbe

eISSN 2686-472X

Table 6. Selected Enterprises on Good Faith Evasion of Tax Revenue

\begin{tabular}{|c|c|c|c|c|c|}
\hline Enterprise & $\begin{array}{c}\text { Principal } \\
\text { tax amount } \\
\text { [a] }\end{array}$ & \begin{tabular}{c}
\multicolumn{2}{c}{ Interest } \\
arrears [b]
\end{tabular} & $\begin{array}{c}\text { Penalty } \\
{[c]}\end{array}$ & $\begin{array}{c}\text { Total Penalty } \\
\text { Sum [d] } \\
{[d]=[b+c]}\end{array}$ & $\begin{array}{c}\text { Total Tax } \\
\text { Amount }[\mathrm{e}] \\
{[\mathrm{e}]=[\mathrm{a}+\mathbf{d}]}\end{array}$ \\
\hline $\begin{array}{l}\text { Ets Tsayem Moses - } 1 \\
\text { Notice No: } 26\end{array}$ & 1355204 & 0 & 659859 & 659859 & 2015063 \\
\hline $\begin{array}{l}\text { Ets Tsayem Moses - } 2 \\
\text { Notice No: } 047\end{array}$ & 1355204 & 327149 & 332710 & 659859 & 3015063 \\
\hline $\begin{array}{l}\text { Ets Tsayem Moses - } 3 \\
\text { Notice No: } 011\end{array}$ & 152464 & 9147 & 45739 & 54886 & 207350 \\
\hline $\begin{array}{l}\text { CAMSUBA }-1 \\
\text { Notice No: } 125\end{array}$ & 298898 & 0 & 179791 & 179791 & 478689 \\
\hline $\begin{array}{l}\text { CAMSUBA }-2 \\
\text { Notice No: } 0346\end{array}$ & 298906 & 90122 & 89669 & 179791 & 478689 \\
\hline $\begin{array}{l}\text { CAMSUBA - } 3 \\
\text { Notice No: } 032\end{array}$ & 3840399 & 0 & 1941592 & 1941592 & 5781991 \\
\hline $\begin{array}{l}\text { UNDVA - } 1 \\
\text { Notice No: } 222\end{array}$ & 2547093 & 163006 & 1406045 & 1569051 & 4116144 \\
\hline $\begin{array}{l}\text { UNDVA - } 2 \\
\text { Notice No: } 32\end{array}$ & 1644152 & 0 & 826521 & 826521 & 2470673 \\
\hline $\begin{array}{l}\text { UNDVA - } 3 \\
\text { Notice No: } 91\end{array}$ & 2707994 & 0 & 974879 & 974879 & 3682873 \\
\hline
\end{tabular}

\section{Source: MTA Consortium}

\section{Bad Faith Evasion of Tax Revenue}

Bad faith penalty to an enterprise is a situation where the tax payer typical and completely refused to pay their business tax even when notified of failure to comply. According to the Cameroon tax code, the bad faith penalty is calculated as: the principal amount of the tax times 100 percent. Considering our table below and with a special focus on the three selected enterprise, we observed Tsayem enterprise with a principal amount of tax to be paid as 405000 FCFA yet evaded the tax and as a consequence under tax administration paid 8010, 000 FCFA, further Camarade pressing, and two periods of UNVDA respectively evaded 258847FCFA, 3672116FCFA and 95131095FCFA amounting to a total of about $9,906,205$. This amount is relatively so high. As a consequence it will be very detrimental for an enterprise to pay, hence revealing that any illegal attempt of bad faith evasion of tax revenue is very harmful for the tax payer enterprise.

Table 7. Selected Enterprises on Bad Faith Evasion of Tax Revenue

\begin{tabular}{|c|c|c|c|c|c|}
\hline Enterprise & $\begin{array}{c}\text { Principal Tax } \\
\text { Amount [a] }\end{array}$ & $\begin{array}{c}\text { Interest } \\
\text { in arrears } \\
{[b]}\end{array}$ & $\begin{array}{c}\text { Penalty } \\
{[c]}\end{array}$ & $\begin{array}{l}\text { Total Penalty } \\
\text { Sum }[d] \\
{[d]=[b+c]}\end{array}$ & $\begin{array}{c}\text { Total Tax } \\
\text { Amount }[\mathrm{e}] \\
{[\mathrm{e}]=[\mathbf{a}+\mathbf{d}]}\end{array}$ \\
\hline $\begin{array}{l}\text { Ets Tsayem } \\
\text { Notice No: } 1169\end{array}$ & 405000 & 0 & 405000 & 405000 & 8010,000 \\
\hline $\begin{array}{l}\text { CAMARADE Pressing } \\
\text { Notice No: } 015\end{array}$ & 258847 & 0 & 258847 & 258847 & 517694 \\
\hline $\begin{array}{l}\text { UNVDA Ndop - } 1 \\
\text { Notice No: } 009\end{array}$ & 3672116 & 848440 & 3452268 & 4300708 & 7972824 \\
\hline $\begin{array}{l}\text { UNVDA Ndop - } 2 \\
\text { Notice No: } 40\end{array}$ & 95131095 & 0 & 38528093 & 38528093 & 133659,188 \\
\hline
\end{tabular}

Source: MTA Consortium 


\section{International Journal of Business Economics (IJBE)}

Vol, 1 Issue 2, pp 87-101, March 2020

http:/ /jurnal.umsu.ac.id/index.php/ijbe

eISSN 2686-472X

\section{Fraudulent Faith Evasion of Tax Revenue}

Fraudulent faith penalty is when the tax payer attempt to evade the tax using illegal means. The penalty is usually calculated as 150 percent times the principal amount of the tax. From table below, usually only very few companies get to fraudulent stage of tax evasion, thus as indicated below, among the many companies existing in North West region only Upper Noun Development Authority committed the act of fraudulent evasion of tax. This implies that instead of spending 13,707,992FCFA as normal principal tax payment to the state treasury as money to be use for government expenditure, may be to build schools, hospitals and in the provision of other social amenities. They ended up paying 66,223,194 FCFA as penalty for the fraudulent payment. All these imply that, a fraudulent evasion of tax can cause a great loss of money to the entire health of the particular business and North West region in particular.

Table 8. Selected Enterprises on Fraudulent Faith Evasion of Tax Revenue

\begin{tabular}{cccccc}
\hline Enterprise & $\begin{array}{c}\text { Principal Tax } \\
\text { Amount [a] }\end{array}$ & $\begin{array}{c}\text { Interest in } \\
\text { arrears [b] }\end{array}$ & Penalty [c] & $\begin{array}{c}\text { Total Penalty } \\
\text { Sum [d]; } \\
{[\mathbf{d}]=[\mathbf{b}+\mathbf{c}]}\end{array}$ & $\begin{array}{c}\text { Total Tax } \\
\text { Amount [e] } \\
{[\mathbf{e}]=[\mathbf{a}+\mathbf{d}]}\end{array}$ \\
\hline $\begin{array}{c}\text { UNVDA } \\
\text { Notice No: 056 } \\
\text { UNVDA }\end{array}$ & 12707993 & 0 & 22519701 & 2012,2015 & 35227694 \\
Notice No: 041 & 9999999 & 0 & 20995501 & $18 / 03 / 2015$ & 30995500 \\
\hline
\end{tabular}

Source: MTA Consortium

\section{CONCLUSION}

This study attempt to examine the Contribution of Tax Consultancy Firm in the Reduction of Tax Evasion: Case of Management of Tax Accounting Consortium, North West Region'. Over the years, revenue derived from taxes has been very low and no physical development actually took place, hence the impact on the poor is not being felt. It is the view of many people that the loss of revenue caused by widespread tax evasion and tax avoidance in Nigeria is due to inefficient and inept tax administration. Different authors have opined that ineffective tax administration is the main factor responsible for large scale tax evasion in Cameroon. Others corroborates this view when they states that tax evasion is due principally to administrative ineffectiveness.

Cameroon is losing billions of FCFA every year to illicit financial tax fraud as individuals and corporate firms engage in fraudulent tax schemes aimed at avoiding tax payments to some of the developing countries, impeding development projects and denying poor people access to crucial services. Tax evasion is major facilitator of poverty, crime, and corruption in a developing country like Cameroon. Tax haven secrecy drains nearly $\$ 1$ trillion from each year from the country. This is money that could have been spent on health care, education, and infrastructure, while banks play a critical role in the global economy and many countries' tax systems; many have also played a significant part in facilitating tax evasion and avoidance schemes, thereby reducing revenue generated by government both at the federal, state and local government level. The main objective of this research work is to assess the contribution of Accounting Firm on tax evasion on the tax payer enterprise. Specifically to: explore the contribution of MTA in the reduction of tax evasion in companies and to investigate the consequences of tax evasion on the tax payer enterprise. Methodologically, we use focus group discussion and quantitative data collected from MTA to determine and estimate our result. 


\section{International Journal of Business Economics (IJBE)}

Vol, 1 Issue 2, pp 87-101, March 2020

http://jurnal.umsu.ac.id/index.php/ijbe

eISSN 2686-472X

The result shows that account firm (MTA) plays a major role in the reduction of tax evasion. Result by tax payer enterprise shows that companies that evade tax being good, bad or fraudulent end up losing much money that may lead to the collapse of the company. In terms of policy implication, we recommend that tax payers should pay their taxes at the appropriate periods and rightly calculated to avoid penalties and interests. The government of Cameroon should absolutely encourage the establishment and growth of accounting firms.

\section{REFERENCES}

Alm J., Bahl R. and Murray M (1990): 'Tax structure and tax compliance', Review of Economics and Statistics, Vol. 42, No. 1, pp.1-33.

Beresford B, Rabiee P and Sloper P (2007): Priorities and Perceptions of Disabled Children and Young People and Their Parents Regarding Outcomes from Support Services, Social Policy Research Unit, University of York, York.

Counterpoint Research (2008): Childhood Wellbeing: Qualitative Research Study. Research Report DCSF-RW031, Department for Children, Schools and Families, London

Dalu T, Maposa V,Pabwaungana S and Tapiwa D (2012): The impact of tax evasion and avoidance on the economy: a case of Harare, Zimbabwe. African J. Economic and Sustainable Development, Vol. 1, No. 3, 2012

Daphne A. Kenyon, Adam H. Langley, and Bethany P. Paquin (2012): Property Tax incentives and pitfalls, National Tax Journal, December 2012, 65 (4), 1011-1022

Fuest, C. and Riedel, N. (2009) 'Tax evasion, tax avoidance and tax expenditures in developing countries: a review of the literature', UK Department for International Development (DFID) report, pp.3-34.

Henry Fayol (2009): Work lifestyle choices in the 21st century; preference theory. New York: Oxford University Press

Kiabel, B.D. and Nwokah, N.G. (2009) 'Curbing tax evasion and avoidance in personal income tax administration: A study of the South-South States of Nigeria', European Journal of Economics, Vol. 15, No. 3, pp.16-61.

Khan M and Manderson L (1992): Focus groups in tropical diseases research, Health Policy and Planning, 7, 56-66

Ndjallè A (2017): Assignment Memorandum on property tax in Cameroun. Research paper presented at the Syracuse University, 23th of March, 2017

Poterba, T. (1987) 'Laws and tax deferred serving', in Wise, D. (Ed.): Topics in Economics Ageing, University of Chicago Press, Chicago, IL.

Ronen G, Rosenbaum P, Law M. and Streiner D (2001): Health-related quality of life in childhood disorders: A modified focus group technique involving children, Quality of Life Research, 10, 1, 71-79.

Rose-Ackermann, W. (1978) 'Tax Illusion and the labour supply of married women', Review of Economics and Statistics, Vol. 58, No. 2, pp.1-13. 